\title{
KAJIAN PENGGUNAAN OBAT KEMOTERAPI PADA PASIEN LEUKEMIA ANAK DI RSUD ABDUL WAHAB SJAHRANIE KOTA SAMARINDA
}

\author{
Andi Cindy Fatikasari*, Welinda Dyah Ayu, Muhammad Amir Masruhim
}

\author{
Laboratorium Penelitian dan Pengembangan Kefarmasian "Farmaka Tropis", \\ Fakultas Farmasi, Universitas Mulawarman, Samarinda, Indonesia \\ *Email: cindyftksr@gmail.com
}

\begin{abstract}
Leukemia is a malignancy of blood cells originate from the bone marrow, characterized by the irregular and uncontrolled proliferation of white blood cells. Acute leukemia is the most common malignancy in children. The purpose of this study is to determine the characteristics of patients, chemotherapy regimens, the accuracy of dosages, side effects of chemotherapy, and treatment of side effects of chemotherapy. The research method used was non-experimental. The data obtained were taken prospectively and the sampling technique was total sampling used medical record data and interview data with a total of 29 respondents. The results of this research showed that patients with acute leukemia were dominated by women with the percentage 52\%, pre-school age group of 3-5 years with the percentage 38\%, and the most types of acute leukemia were ALL type L1 with the percentage 59\%. The most leukemia chemotherapy regimens is a combination of Methotrexate IT-Vincristine with the percentage 37\% and the accuracy of dosages with the percentage 100\% is calculated based on BSA (Body Surface Area). The side effects most experienced by patients with leukemia chemotherapy is nausea-vomiting with the percentage $97 \%$ and the treatment of nausea-vomiting side effects is ondansetron.
\end{abstract}

Keywords: leukemia, characteristics, regimen, side effects

\begin{abstract}
ABSTRAK
Leukemia merupakan penyakit keganasan sel darah yang berasal dari sumsum tulang, ditandai oleh proliferasi sel-sel darah putih yang tidak teratur dan tidak terkendali. Leukemia akut adalah keganasan yang paling umum terjadi pada anak-anak. Tujuan penelitian ini yaitu untuk mengetahui karakteristik pasien, regimen kemoterapi, ketepatan dosis, efek samping serta penanganan efek samping kemoterapi leukemia. Metode penelitian yang digunakan yaitu non eksperimental. Data yang di peroleh diambil secara prospektif dan teknik pengambilan data secara total sampling menggunakan data rekam medik serta data hasil wawancara dengan jumlah total sebanyak 29 responden. Hasil penelitian menunjukkan bahwa pasien yang mengalami leukemia akut lebih banyak diderita oleh perempuan sebesar 52\%, pada kelompok usia pra-sekolah 3-5 tahun sebesar $38 \%$, dan jenis leukemia akut terbanyak adalah jenis ALL tipe $\mathrm{L}_{1}$ sebesar 59\%. Regimen kemoterapi leukemia terbanyak adalah kombinasi Methotrexate IT-Vincristin sebesar 37\% dengan ketepatan dosis sebesar 100\% dihitung berdasarkan BSA (Body Surface Area).
\end{abstract}


Efek samping regimen kemoterapi terbanyak adalah mual-muntah sebesar 97\% dengan penanganan efek samping mual-muntah adalah ondansetron.

Kata Kunci : leukemia, karakteristik, regimen, efek samping

DOI: https://doi.org/10.25026/mpc.v8i1.312

\section{PENDAHULUAN}

Leukemia merupakan penyakit keganasan sel darah yang berasal dari sumsum tulang, ditandai oleh proliferasi sel-sel darah putih yang secara tidak teratur dan tidak terkendali dan fungsinya pun menjadi tidak normal, dengan manifestasi adanya sel-sel abnormal dalam darah tepi[1]. Berdasarkan data dari American Cancer Society (ACS) tahun 2012, menunjukkan bahwa di Amerika Serikat pada tahun 2012, leukemia menjadi sepertiga dari semua keganasan yang terjadi pada anak dan sering ditemukan pada anak di bawah usia 15 tahun[2].

Leukemia akut dikelompokkan menjadi Leukemia Limfoblastik Akut (ALL) yang memiliki persentase kirakira $75 \%$ dari semua kasus dengan insiden tertinggi pada umur 4 tahun dan Leukemia Mieloblastik Akut (AML) yang memiliki persentase $20 \%$ dengan insidensi yang tetap dari lahir sampai umur 10 tahun[3].

Penatalaksanaan terapi pada pasien leukemia, salah satunya adalah kemoterapi. Pemberian obat antikanker merupakan tindakan utama untuk mengeliminasi sel-sel kanker dalam tubuh. Regimen kemoterapi leukemia dan pemberian dosis pada pasien berbedabeda sesuai dengan jenis leukemia, berat badan, dan tinggi badan pasien yang apabila terjadi kesalahan dapat menimbulkan ketidaktepatan terapi yang diberikan kepada pasien leukemia[4]. Selain itu, adapula beberapa efek samping yang perlu diperhatikan akibat dari kemoterapi, hal ini disebabkan karena obat-obat kemoterapi tidak hanya menghancurkan sel-sel kanker tetapi juga menyerang sel-sel sehat, terutama sel-sel yang membelah dengan cepat.

Berdasarkan uraian di atas, peneliti tertarik untuk melakukan penelitian mengenai kajian penggunaan obat kemoterapi untuk mengetahui karakteristik, pola pengobatan, dan efek samping serta penanganan dari efek samping kemoterapi pada pasien leukemia anak di Rumah Sakit Umum Daerah Abdul Wahab Sjahranie Samarinda.

\section{METODE PENELITIAN}

Metode penelitian yang digunakan dalam penelitian ini adalah penelitian non eksperimental dengan penelusuran data secara prospektif dengan menggunakan data rekam medik serta data hasil wawancara dengan pasien leukemia di Rumah Sakit Umum Daerah Abdul Wahab Sjahranie Samarinda.

Pengambilan sampel ditentukan menggunakan metode total sampling yang sesuai dengan kriteria inklusi. Jumlah sampel pada penelitian ini sebanyak 29 pasien. Kriteria inklusi pada penelitian ini yaitu pasien dengan diagnosa leukemia akut dan sedang menjalani kemoterapi di RSUD Abdul Wahab Sjahranie Samarinda dan berusia 0-12 tahun. Data yang di peroleh dianalisis secara deskriptif dan dibuat tabulasi data. 
Tabel 1. Distribusi Karakteristik Pasien Leukemia Anak Berdasarkan Usia

\begin{tabular}{ccc}
\hline Usia (tahun) & Jumlah Pasien & Persentase (\%) \\
\hline $0-1$ & 2 & 7 \\
$1-3$ & 6 & 21 \\
$3-5$ & 11 & 38 \\
$5-12$ & 10 & 34 \\
\hline Total & 29 & 100 \\
\hline
\end{tabular}

Tabel 2. Distribusi Karakteristik Pasien Leukemia Anak Berdasarkan Jenis Kelamin

\begin{tabular}{ccc}
\hline Jenis Kelamin & Jumlah Pasien & Persentase (\%) \\
\hline Laki - laki & 14 & 48 \\
Perempuan & 15 & 52 \\
\hline Total & 29 & 100 \\
\hline
\end{tabular}

\section{HASIL DAN PEMBAHASAN}

\section{Karakteristik Pasien Leukemia Anak}

Penelitian ini dilakukan di RSUD

Abdul Wahab Sjahranie Samarinda. Responden yang dikumpulkan pada penelitian ini sebanyak 29 orang. Dari 29 orang responden tersebut selanjutnya dianalisis karakteristiknya berdasarkan usia, jenis kelamin, dan jenis leukemia.

Berdasarkan Tabel 1 diperoleh rentang usia 3-5 tahun memiliki angka kejadian leukemia akut paling tinggi yaitu dengan persentase sebesar 38\% (11 pasien) dan tidak berbeda jauh dengan rentang usia 5-12 tahun yang memiliki persentase sebesar 34\% (10 pasien). Hal ini sejalan dengan penelitian Pertiwi (2013) yang menunjukkan leukemia paling banyak diderita pada anak usia 3-6 tahun dengan persentase 40\%[5]. Penelitian Puspita (2018) yang melaporkan bahwa kasus leukemia anak terbanyak pada rentang usia 1-6 tahun dengan persentase $56,6 \%[6]$, dan penelitian Fridayenti (2015) yang menunjukkan anak usia 5-9 tahun dengan persentase tertinggi sebesar 46,2\%[7].

Secara keseluruhan leukemia dapat terjadi pada berbagai rentang usia dengan puncak kejadian ALL yaitu pada rentang usia 2-5 tahun[8]. Usia tersebut dikategorikan dalam usia pra-sekolah dimana usia tersebut adalah masa dimana anak-anak dapat menunjukkan kemampuan untuk lebih banyak beraktivitas, mengembangkan rasa ingin tahu dan eksplorasi terhadap benda yang ada di sekelilingnya[9].

Berdasarkan Tabel 2 diperoleh bahwa perempuan memiliki angka kejadian leukemia akut lebih tinggi yaitu dengan persentase sebesar 52\% (15 pasien) dibandingkan dengan laki-laki. Hal ini bertentangan dengan penelitian Pertiwi (2013) dimana kasus leukemia dengan jenis kelamin laki-laki lebih tinggi dibandingkan perempuan[5] Data dari SEER Amerika (2011) menunjukkan bahwa kejadian leukemia lebih tinggi pada laki-laki daripada perempuan[10]. Penelitian Chandrayani (2009) juga menunjukkan bahwa leukemia lebih banyak diderita oleh anak laki-laki dibandingkan perempuan dengan perbandingan 10:3[11].

Hal ini menunujukkan bahwa risiko menderita leukemia pada anak yang berjenis kelamin laki-laki lebih besar dibandingkan dengan yang berjenis kelamin perempuan. Banyak faktor yang dapat menyebabkan perbedaan hasil 
penelitian yang didapatkan diantaranya yaitu faktor kondisi lingkungan yang buruk, gaya hidup masyarakat, serta faktor kondisi kesehatan[12].

Berdasarkan Tabel 3. diperoleh jenis leukemia yang paling banyak diderita oleh pasien anak adalah Leukemia Limfoblastik Akut (ALL) tipe L1 dengan persentase sebesar 59\% (16 pasien). Hal ini sejalan dengan penelitian Wijayanti (2017) yang menunjukkan bahwa ALL yang paling banyak terjadi adalah tipe L1 dengan persentase sebesar 63,4\%[13]. Sedangkan Leukemia Myeloblastik Akut (AML) terdapat 2 pasien dengan tipe M5 sebesar $50 \%$ (1 pasien) dan tipe M6 sebesar $50 \%$ (1 pasien).

Penelitian ini menunjukkan bahwa jenis leukemia anak di RSUD Abdul Wahab Sjahranie terbagi menjadi dua jenis leukemia akut yaitu Leukemia Limfoblastik Akut (ALL) 97\% dan Leukemia Myeloblastik Akut (AML) 7\%. Menurut Permono (2012) pada populasi anak, umumnya jenis leukemia yang terjadi adalah ALL dan AML. Kasus ALL (82\%) lebih sering terjadi pada anak dibandingkan dengan AML (18\%) dan
AML bisa menyerang segala usia, tetapi paling sering terjadi pada umur dewasa[14].

Menurut klasifikasi FAB (French American British) kasus ALL dibagi menjadi 3 subtipe berdasarkan morfologi lymphoblast atau sel darah putih yang terinfeksi. ALL-L 1 terdiri dari sel-sel limfoblas kecil serupa dengan kromatin homogen, anak inti umumnya tidak tampak dan sitoplasma sempit, ALL-L2 sel limfoblas lebih besar tetapi ukurannya bervariasi, kromatin lebih besar dengan satu atau lebih anak inti dan ALL-L L $_{3}$ sel limfoblas besar, homogen dengan kromatin berbercak, banyak ditemukan anak inti serta sitoplasma yang basofilik dan bervakuolisasi. Sedangkan untuk kasus AML dibagi menjadi 8 subtipe yaitu M0 (AML tanpa maturasi), M1 (AML berdiferensiasi minimal), M2 (AML dengan maturasi), M3 (leukemia promielositik hipergranuler), M4 (leukemia mielomonositik akut), M5 (leukemia monositik akut), M6 (leukemia eritroblastik), dan M7 (leukemia megakariositik akut)[8].

Tabel 3. Distribusi Karakteristik Pasien Leukemia Berdasarkan Jenis Leukemia

\begin{tabular}{cccc}
\hline \multicolumn{2}{c}{ Jenis Leukemia } & Jumlah Pasien & \multirow{2}{*}{ Persentase (\%) } \\
\hline Tipe & Subtipe & & 59 \\
ALL & L1 & 16 & 41 \\
$(\mathrm{n}=93 \%)$ & L2 & 11 & 0 \\
\hline Total & L3 & 0 & 100 \\
\hline & M0 & 27 & 0 \\
& M1 & 0 & 0 \\
AML & M2 & 0 & 0 \\
$(\mathrm{n}=7 \%)$ & M3 & 0 & 0 \\
& M4 & 0 & 0 \\
& M5 & 1 & 50 \\
& M6 & 1 & 50 \\
Motal & M7 & 0 & 0 \\
\hline
\end{tabular}


Tabel 4. Regimen Kemoterapi Leukemia Limfoblastik Akut (ALL)

\begin{tabular}{cccc}
\hline $\begin{array}{c}\text { Regimen Kemoterapi } \\
\text { ALL }\end{array}$ & $\begin{array}{c}\text { Dosis Literatur } \\
(\mathrm{DIH}, 2013)\end{array}$ & $\begin{array}{c}\text { Jumlah } \\
\text { Pasien }\end{array}$ & $\begin{array}{c}\text { Persentase } \\
(\%)\end{array}$ \\
\hline $\begin{array}{c}\text { Methotrexate IT } \\
\text { Vincristin }\end{array}$ & $\begin{array}{c}6-12 \mathrm{mg} / \mathrm{dosis} \\
1,5 \mathrm{mg} / \mathrm{m}^{2}\end{array}$ & 10 & 37 \\
\hline Vincristin & $1,5 \mathrm{mg} / \mathrm{m}^{2}$ & 6 & 22 \\
\hline $\begin{array}{c}\text { Methotrexate IT } \\
\text { Vincristin }\end{array}$ & $\begin{array}{c}6-12 \mathrm{mg} / \mathrm{dosis} \\
1,5 \mathrm{mg} / \mathrm{m}^{2}\end{array}$ & 5 & 19 \\
Daunorubicin & $25 \mathrm{mg} / \mathrm{m}^{2}$ & & \\
L-asparaginase & $6000 \mathrm{U} / \mathrm{m}^{2}$ & & 15 \\
\hline Methotrexate IT & $6-12 \mathrm{mg} / \mathrm{dosis}^{2}$ & & \\
HD Methotrexate & $1000 \mathrm{mg} / \mathrm{m}^{2}$ & 4 & 7 \\
Leucovorin & $10-15 \mathrm{mg} / \mathrm{m}^{2}$ & & 100 \\
\hline Methotrexate IT & $6-12 \mathrm{mg} / \mathrm{dosis}^{2}$ & & \\
Vincristin & $1,5 \mathrm{mg} / \mathrm{m}^{2}$ & 2 & \\
Citarabin & $75 \mathrm{mg} / \mathrm{m}^{2}$ & & \\
\hline Total & & 27 & \\
\hline
\end{tabular}

Tabel 5. Regimen Kemoterapi Leukemia Myeloblastik Akut (AML)

\begin{tabular}{cccc}
\hline $\begin{array}{c}\text { Regimen Kemoterapi } \\
\text { AML }\end{array}$ & $\begin{array}{c}\text { Dosis Literatur } \\
(\mathrm{DIH}, 2013)\end{array}$ & $\begin{array}{c}\text { Jumlah } \\
\text { Pasien }\end{array}$ & $\begin{array}{c}\text { Persentase } \\
(\%)\end{array}$ \\
\hline Methotreksat IT & $\begin{array}{c}6-12 \mathrm{mg} / \mathrm{dosis} \\
75 \mathrm{mg} / \mathrm{m}^{2}\end{array}$ & 1 & 50 \\
Citarabin & $25 \mathrm{mg} / \mathrm{m}^{2}$ & & \\
Daunorubicin & $1,5 \mathrm{mg} / \mathrm{m}^{2}$ & & 50 \\
\hline Vincristin & $\begin{array}{c}75 \mathrm{mg} / \mathrm{m}^{2} \\
\text { Citarabin }\end{array}$ & 1 & 100 \\
Doxorubicin & $20-30 \mathrm{mg} / \mathrm{m}^{2}$ & & \\
\hline Total & & 2 & \\
\hline
\end{tabular}

\section{Pola Pengobatan Kemoterapi Pasien Leukemia}

Penelitian ini menunjukkan persentase pemilihan regimen kemoterapi berdasarkan jenis leukemia. Pola pengobatan leukemia di RSUD Abdul Wahab Sjahranie didasarkan pada Indonesian ALL 2013 Protocol oleh Ikatan Dokter Anak Indonesia (IDAI). Berdasarkan tabel 4. diperoleh regimen kemoterapi ALL yang paling banyak adalah Methotrexate IT-Vincristin dengan persentase sebesar $37 \% \quad(10$ pasien). Pada tabel 5. diperoleh regimen kemoterapi AML yaitu Methotreksat ITCitarabin-Daunorubicin persentase $50 \%$ (1 pasien) dan kombinasi Vincristin-Citarabin-Doxorubicin dengan persentase $50 \%$ (1 pasien).

Kombinasi obat kemoterapi ALL Methotreksat IT-Vincristin merupakan obat yang digunakan pada fase pemeliharaan (maintenance) dengan dosis methotreksat IT 6-12 mg/dosis yang disesuaikan dengan usia pasien dan vincristin dosis $1,5 \mathrm{mg} / \mathrm{m}^{2}$. Kombinasi obat kemoterapi AML Methotreksat ITCitarabin-Daunorubicin yang digunakan pada fase induksi dan kombinasi Vincristin-Citarabin-Doxorubicin pada fase konsolidasi. Methotrexate merupakan obat golongan antimetabolit 
antagonis folat, dimana obat ini bekerja dengan menghambat dihidrofolat reduktase yang mengubah asam folat menjadi asam tetrahidrofolat sehingga sintesis protein dan asam nukleat terganggu yang menyebabkan kematian sel. Vincristin merupakan alkaloid vinka yang berikatan secara spesifik dengan tubulin, komponen protein mikrotubulus, spindle mitotic, dan memblok polimerisasi sel sehingga terjadi disolusi mikrotubulus dan sel terhenti dalam proses metafase[15].

Pengobatan leukemia dibagi menjadi beberapa tahapan yaitu fase induksi yang berlangsung selama 4-6 minggu untuk mencapai remisi, fase postremisi dimana fase ini untuk mempertahankan remisi selama mungkin hingga menuju kesembuhan yang dicapai dengan fase konsolidasi dan pemeliharaan yang berlangsung selama 2-3 tahun[14].
Obat akan memberikan efek yang maksimal apabila diberikan dengan dosis, cara dan lama pemberian yang tepat. Pada penelitian ini, ketepatan dosis kemoterapi yang diberikan kepada pasien leukemia anak di instalasi rawat inap RSUD Abdul Wahab Sjahranie dibandingkan dengan guideline dari Indonesian ALL 2013 Protocol dan Drug Information Handbook. Pemberian dosis kemoterapi pada setiap pasien dapat dilakukan dengan menggunakan rumus Body Surface Area (BSA) yang dihitung menggunakan data tingi badan dan berat badan pasien. Berdasarkan hasil penelitian yang didapatkan semua pasien leukemia anak di RSUD AWS mendapatkan dosis yang sesuai dengan guidline yang dihitung berdasarkan BSA dengan persentase sebesar $100 \% \quad$ (29 pasien).

Tabel 6. Efek Samping Regimen Kemoterapi Leukemia

\begin{tabular}{ccccc}
\hline Obat Kemoterapi & Efek Samping (DIH, 2014) & Terapi Suportif & $\begin{array}{c}\text { Jumlah } \\
\text { Pasien }\end{array}$ & $\begin{array}{c}\text { Persentase } \\
(\%)\end{array}$ \\
\hline $\begin{array}{c}\text { Methotrexate IT } \\
\text { Daunorubicin } \\
\text { Doxorubicin }\end{array}$ & Mual & Ondansetron & 28 & 97 \\
\hline $\begin{array}{c}\text { Methotrexate IT } \\
\text { Daunorubicin } \\
\text { Doxorubicin }\end{array}$ & Muntah & Ondansetron & 28 & 97 \\
\hline Vincristin & Alopecia (Rambut rontok) & - & 18 & 62 \\
\hline $\begin{array}{c}\text { Methotrexate IT } \\
\text { Doxorubicin }\end{array}$ & Stomatitis & Nistatin & 19 & 65 \\
\hline $\begin{array}{c}\text { Methotrexate IT } \\
\text { Citarabin }\end{array}$ & Trombositopenia & Transamin & 9 & 31 \\
\hline Daunorubicin & Diare & Oralit & 5 & 17 \\
\hline Citarabin & Penurunan nafsu makan & Multivitamin & 11 & 38 \\
\hline $\begin{array}{c}\text { Daunorubicin } \\
\text { Vincristin }\end{array}$ & Anemia & $\begin{array}{c}\text { PRC (Packed } \\
\text { Red blood Cells })\end{array}$ & 25 & 86 \\
\hline $\begin{array}{c}\text { L-Asparaginase } \\
\text { Leucovorin }\end{array}$ & Hipersensitifitas & Cetirizine & 6 & 21 \\
\hline Vincristin & Konstipasi & Laksatif & 1 & 3 \\
\hline
\end{tabular}


Berdasarkan tabel 6. diperoleh bahwa efek samping dari kemoterapi yang paling sering terjadi adalah mual-muntah dengan persentase sebesar 97\% (28 pasien). Hal ini disebabkan karena sebagian besar dari obat kemoterapi leukemia memiliki potensi emetogenik (mual-muntah). Obat-obat kemoterapi leukemia yang memiliki resiko emesis sedang adalah Doxorubicin, Daunorubicin, Metotreksat $1000 \mathrm{mg} / \mathrm{m}^{2}$ (frekuensi emesis >30-90\%), resiko emesis rendah adalah Citarabin (frekuensi emesis 10-30\%), dan obat dengan resiko emesis ringan adalah Vincristin, Asparaginase, Metotreksat $<50 \mathrm{mg} / \mathrm{m}^{2}$ (frekuensi emesis 1-10\%)[16].

Mual dan muntah pada pasien leukemia umumnya terjadi karena efek samping pengobatan kemoterapi yang bersifat membunuh sel kanker, sel normal, ataupun sel yang baru tumbuh (berkembang). Mual merupakan perasaan tidak nyaman dikerongkongan dan perut yang menyebabkan muntah, sedangkan muntah dipicu oleh impuls aferen ke pusat muntah (yang berlokasi di medulla) dari chemoreseptor trigger zone, faring dan saluran pencernaan, dan korteks serebral yang disebabkan oleh obat-obat kemoterapi. Penanganan untuk efek samping mual dan muntah dapat diatasi dengan pemberian antiemetik sebelum atau sesudah kemoterapi. Obat antiemetik yang digunakan didasarkan pada tingkat emetogenik dari regimen kemoterapi dan penggunaan regimen antiemetik berdasarkan target reseptor yang bervariasi. Berdasarkan hasil penelitian di RSUD Abdul Wahab Sjahranie diperoleh bahwa penanganan untuk mual muntah adalah dengan pemberian ondansetron yang diberikan secara intravena 30 menit sebelum kemoterapi[16].

Selain mual-muntah adapula alopecia atau rambut rontok dengan persentase sebesar 62\% (18 pasien) terjadi akibat dari obat-obat kemoterapi menekan proses mitosis matriks rambut, dimana efek samping ini tidak diberikan terapi suportif karena rambut dapat tumbuh kembali setelah terapi selesai [17]. Stomatitis dengan persentase sebesar 65\% (19 pasien) terjadi akibat dari kerusakan membran mukosa yang menyebabkan infeksi (kandidiasis mulut), dimana terapi suportif yang diberikan dalam penelitian ini adalah nistatin yang merupakan obat golongan antijamur [18]. Anemia dengan persentase $86 \% \quad(25$ pasien) terjadi akibat obat-obat kemoterapi menekan proses pembentukan sel darah yang menyebabkan kurangnya produksi sel darah merah, dimana terapi suportif yang diberikan dalam penelitian ini adalah pemberian PRC (Packed Red blood Cells) $10 \mathrm{ml} / \mathrm{kgBB}$ selama 3-4 jam, PRC diberikan untuk kondisi anemia berat dimana kadar $\mathrm{Ht} \leq 12 \%$ atau $\mathrm{Hb} \leq 4$ g/dl [19].

\section{KESIMPULAN}

Berdasarkan hasil penelitian kajian penggunaan obat kemoterapi pada pasien leukemia anak di RSUD Abdul Wahab Sjahranie Samarinda yang telah dilakukan dapat disimpulkan bahwa :

1. Karakteristik berdasarkan Usia terbanyak pada usia 3-5 tahun dengan persentase $38 \%$, berdasarkan jenis kelamin terbanyak adalah perempuan dengan persentase $52 \%$ dan berdasarkan jenis leukemia yang paling banyak diderita pasien adalah ALL tipe $\mathrm{L}_{1}$ dengan persentase $59 \%$.

2. Pola pengobatan kemoterapi berdasarkan pemilihan jenis dan golongan obat kemoterapi terbanyak adalah Methotrexate IT-Vincristin dengan persentase 37\% (10 pasien). Dosis pemberian obat kemoterapi telah sesuai dengan hasil perhitungan dosis berdasarkan Body Surface Area (BSA).

3. Efek samping pengobatan kemoterapi terbanyak yang dialami pasien adalah mual-muntah dengan persentase $97 \%$ (28 pasien) serta penanganan untuk efek samping mual-muntah adalah ondansetron. 
UCAPAN TERIMAKASIH

Terimakasih kepada Pimpinan RSUD Abdul Wahab Sjahranie Samarinda atas izin dan bantuan yang diberikan selama penelitian.

\section{DAFTAR PUSTAKA}

[1] Permono, B., et al., Buku ajar hematologi-onkologi anak. 2006: p. 138-9.

[2] Society, A.C., Cancer Facts dan Figures 2012. 2012.

[3] Anky TR, A.M., Sari Y, Edi ST, Karakteristik Leukemia Limfoblastik Akut pada Anak di Rumah Sakit Kanker "Dharmais" 2000-2008. Indonesian Journal of Cancer. 2010, 2010. 4(4).

[4] Junaidi, I.J.J.P.B.I.P., Kanker. 2007.

[5] Pertiwi, N.M.I., et al., Potensi Toksisitas Neurologis Vinkristin Pada Tubuh Yang Terjadi Pada Anak Dengan Leukemia Limfositik Akut. 2013. 7(2): p. 186-194.

[6] Puspita, E., H.S. Mediani, and I.J.J.P.K.I. Nurhidayah, Correlation between Nutritional States with Hematological Toxicity in Children with Acute Lymphoblastic Leukemia. 2018. 4(1): p. 22-29.

[7] Fridayenti, F., H. Masdar, and S.J.J.I.K. Asriani, Profil Pasien Leukemia Anak di RSUD Arifin Achmad Provinsi Riau Periode Tahun 2013-2014. 2017. 9(2): p. 7886.

[8] Kumar, V., et al., Buku ajar patologi Robbins. 2015: Elsevier (Singapore).

[9] Supartini, Y., Buku ajar konsep dasar keperawatan anak. 2004, Jakarta: Egc.

[10] Institute, N.C., Surveilance Epidemiology and End Results (SEER) Leukemia Cancer Statistics Review. 2011.
[11]S, C., Gambaran Distribusi Frekuensi Leukemia di RSK Dharmais dari Tahun 2004-2008. Skripsi, 2009.

[12]Rahmadin, B., I. Wahid, and R.J.J.K.A. Yaswir, Profil Penderita Leukemia Mieloblastik Akut di Bagian Penyakit Dalam RSUP Dr. M. Djamil Padang. 2018. 6(3): p. 495-501.

[13] WIJAYANTI, L.P. and E.J.I.J.o.C. SUPRIYADI, Faktor Prognostik dan Kesintasan Pasien Leukemia Limfoblastik Akut Anak di RSUP Dr. Sardjito, Yogyakarta, 2010-2015. 2018. 11(4): p. 145-150.

[14]Permono, B., dan Ugrasena, I, Buku Ajar Hematologi Onkologi Anak. 2012.

[15] Gunawan, S.G., R. Setiabudy, and E.J.E. Nafrialdi, Farmakologi dan terapi. 2007. 5: p. 139-160.

[16] Network, N.C.C., Clinical Practice Guidlines in Oncology : Antiemesis. 2018.

[17]Faisel, $\quad$ C.T.W.J.J.M.P.F.U.T., Gambaran efek samping kemoterapi berbasis antrasiklin pada pasien kanker payudara di RSUD dokter Soedarso pontianak. 2012. 1(1).

[18] Oberbaum, M., et al., A randomized, controlled clinical trial of the homeopathic medication TRAUMEEL $s \circledR$ in the treatment of chemotherapy-induced stomatitis in children undergoing stem cell transplantation. 2001. 92(3): p. 684690.

[19]Kar, A.S., Pengaruh anemia pada kanker terhadap kualitas hidup dan hasil pengobatan. 2005. 